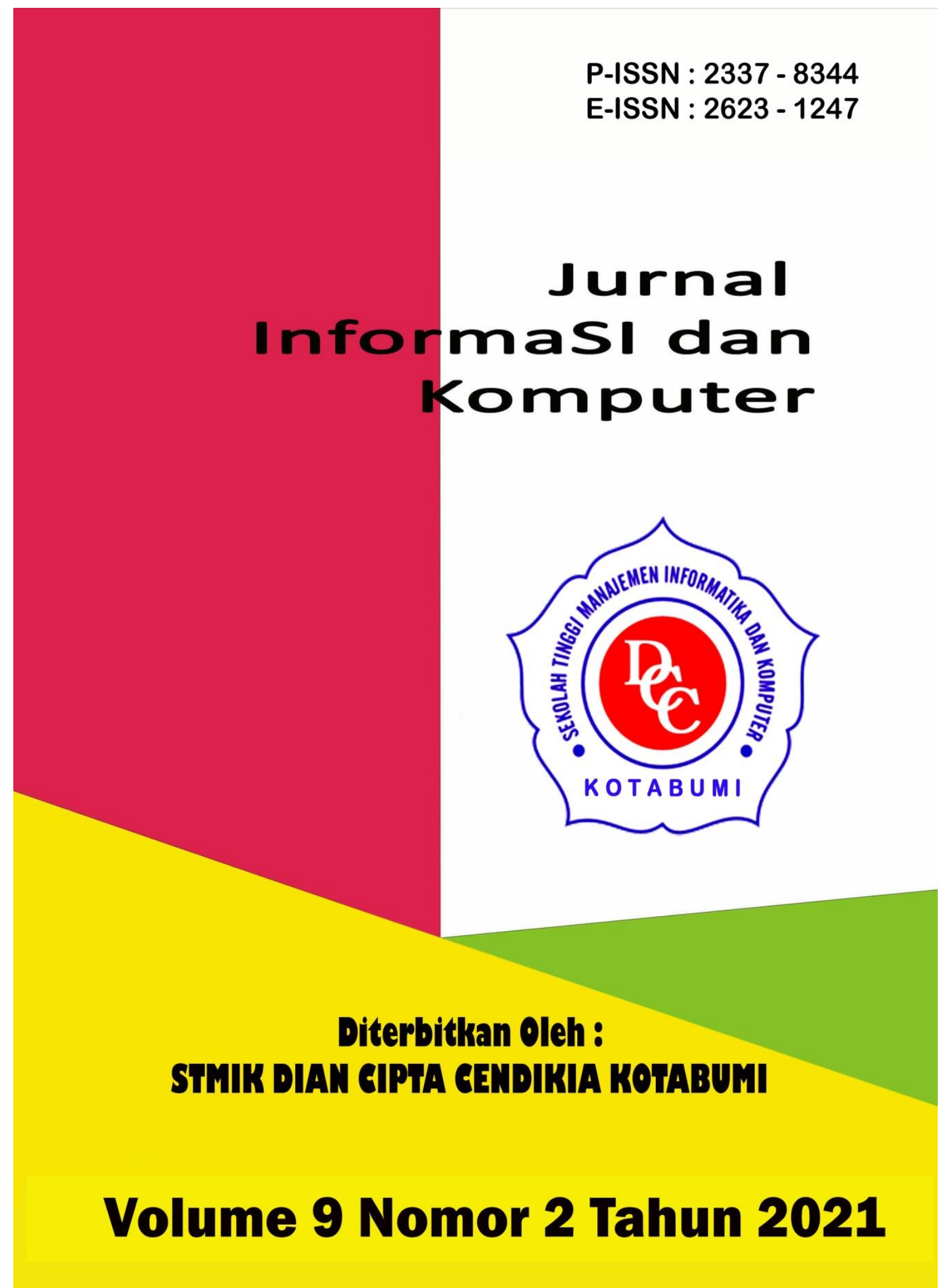




\section{Penerbit}

\section{Lembaga Penelitian STMIK Dian Cipta Cendikia Kotabumi}

Hak atas naskahh/tulisan tetap berada pada penulis, isi diluar tangung jawab penerbit dan Dewan Penyunting 


\section{PENGANTAR REDAKSI}

Puji syukur dipanjatkan kehadirat Tuhan Yang Maha Esa, atas karunia dan limpahan rahmatNYA jualah Jurnal Informasi dan komputer (JIK) STMIK Dian Cipta Cendikia Kotabumi ini dapat terwujud.Jurnal Informasi dan Komputer (JIK) yang terbit dua (2) kali dalam setahun ini merupakan suatu wadah untuk penyebar luasan hasil-hasil penelitian, studi pustaka, karya ilmiah yang berkaitan dengan Informasi dan Komputer khususnya bagi dosen-dosen STMIK Dian Cipta Cendikia Kotabumi serta umumnya para cendikiawan, praktisi, peneliti ilmu Informatika dan Komputer.

Harapan, dengan diterbitkannya Jurnal Informasi dan Komputer (JIK) ini sebagai salah satu bentuk sumbangan pemikiran dalam pengembangan ilmu informatika dan komputer yang berkaitan dengan kajian-kajian di bidang tekhnologi Informatik, Komunikasi Data dan Jaringan Komputer, perancangan dan Rekayasa Perangkat Lunak, serta ilmu-ilmu yang terkait dengan bidang Informasi dan Komputer lainnya.

Berkenaan dengan harapan tersebut, kepada para peneliti, dosen dan praktisi yang memiliki hasil-hasil penelitian, kajian pustaka, karya ilmiah dalam bidang tersebut diatas, dengan bangga redaksi Jurnal Informasi dan Komputer (JIK) menerima naskah ringkasan untuk dimuat pada jurnal Informasi dan Komputer (JIK) STMIK Dian Cipta Cendikia Kotabumi dengan berpedoman pada penulisan naskah jurnal sebagaimana dilampirkan pada halaman belakang (Bagian kulit dalam) buku jurnal ini.

Mutu dari suatu jurnal ilmiah tidak hanya ditentukan oleh para pengelolanya saja, tetapi para penulis dan pembaca jualah yang mempunyai peranan besar dalam meningkatkan mutu jurnal Informatika dan Komputer ini. Merujuk pada realita ini kamu sangat mengharapkan peran aktif dari peneliti untuk bersama-sama menjaga dan memelihara keberlangsungan dari jurnal Informasi dan Komputer STMIK Dian Cipta Cendikia Kotabumi ini. Yang juga tidak kalah pentingnya dari partisipasi tersebut diatas, adalah saran dan kritik yang membangun dari pembaca yang budiman agar kiranya dapat disampaikan langsung kepada redaksi JIK. Saran dan kritik yang membangun akan dijadikan masukan dan pertimbangan yang sangat berarti guna peningkatan mutu dan kualitas Jurnal Informasi dan Komputer STMIK Dian Cipta Cendikia Kotabumi.

Tak lupa diucapkan terima kasih yang tak terhingga atas perhatian dan kerjasama dari semua pihak yang tak dapat disebutkan satu persatu hingga dapat diterbitkan nya Jurnal Informasi dan Komputer (JIK) STMIK Dian Cipta Cendikia Kotabumi. Semoga apa yang telah diperbuat untuk kebaikan akan menjadi amal ibadah, amin.

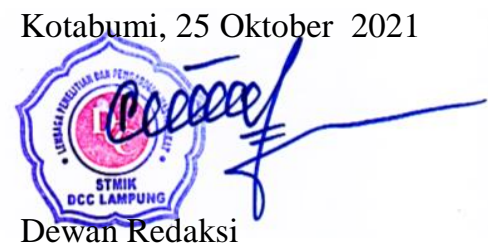




\section{JURNAL INFORMASI DAN KOMPUTER}

Volume 9 Nomor 2 Oktober 2021

Jurnal Informasi dan Komputer merupakan Sarana informasi ilmu pengetahuan, Tekhnologi dan Komunikasi yang berupa hasil penelitian, tulisan ilmiah, Ataupun studi pustaka. Jurnal ini terbit dua kali setahun pada bulan April dan Oktober. Berisi hasil penelitian ilmiah di bidang informatika yang bertujuan untuk menghubungkan adanya kesenjangan antar kemajuan teknologi dan hasil penelitian. Jurnal ini di terbitkan pertama kali pada tahun 2013.

Penanggung Jawab:

Ketua STMIK Dian Cipta Cendikia Kotabumi

\section{Pembina:}

Ketua STMIK Dian Cipta Cendikia Kotabumi Ketua Lembaga Penelitian STMIK Dian Cipta Cendikia Kotabumi

\section{Pimpinan Redaksi}

Dwi Marisa Efendi,.S.Kom.,M.Ti

\section{Redaksi pelaksana}

Rustam,.S.Kom,.M.Ti (STMIK Dian Cipta Cendikia Kotabumi)

Nurmayanti M.Kom (STMIK Dian Cipta Cendikia Kotabumi)

Sukatmi,.S.Kom., M.Kom (AMIK DCC Bandar Lampung)

Sampurna Dadi Riskiono,M.Kom (Universitas Teknokrat Indonesia)

Ifo Wahyu Pratama,S.Kom.,M.Ti(AMIK MASTER Lampung)

\section{Mitra Bestari}

Dr. RZ. ABDUL AZIZ, ST., MT (Institut Informatika dan Bisnis Darmajaya)

Dr. Dadang Sudrajat, S.Si, M.Kom (STMIK IKMI Cirebon)

Dr. Septafiansyah Dwi Putra, S.T., M.T (Politeknik Negeri Lampung)

Dr. Evi Grativiani, S.E., M.S.I (Universitas Sebelas Maret)

Rohmat Indra Borman ( Universitas Teknokrat Indonesia )

Ferry Wongso, S.KOm., M.Kom ( STMIK Darma Pala Riau)

Ferly Ardhy, S.Kom., M.Ti ( Universitas Aisyah Pringsewu )

Firmansyah, S.E., M.Si (STMIK Darma Pala Riau)
Amarudin (Universitas Teknokrat Indonesia)

Didi Susianto, S.T., M.Kom (AMIK Dian Cipta Cendika Bandar Lampung)

Alhibarsyah, St., M.Kom (STMIK Tunas

Bangsa Bandar Lampung)

Kemal Farouq Mauladi, S.Kom .M.Kom (Universitas Islam Lamongan)

Rima Mawarni, M.Kom ( STMIK Dian Cipta Cendikia Kotabumi)

Wira Jaya Hartono, S.Pd., M.Pd ( STMIK Darma Pala Riau)

Penerbit : STMIK Dian Cipta Cendikia Kotabumi Bekerja Sama Dengan LPPM STMIK Dian Cipta Cendikia Kotabumi.

\section{Alamat Redaksi/Penerbit:}

Jl. Negara No. 3 Candimas Kotabumi Lampung Utara

No Telpon/Fax 072423003

Email : 1ppm-stmik@dcc.ac.id 


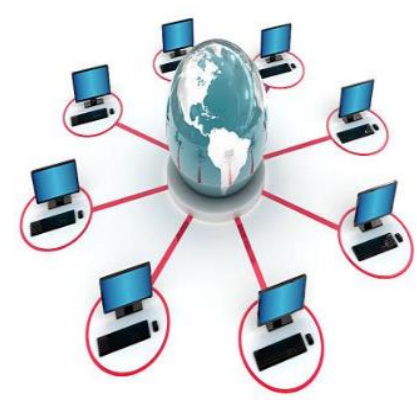

\section{JURNAL INFORMASI DAN KOMPUTER VOL. 9 NO. 2 THN. 2021}

\section{DAFTAR ISI}

Halaman

Sistem Informasi Akuntansi Persedian Barang Berbasis Web Pada Lembaga

Permasyarakatan Kelas II A Banceuy Bandung : "Kelompok Tani Desa Banjar Kertarahayu" Teuku Rian Hardiyansyah, Fatia Salsa Azzahra (Politeknik Piksi Ganesha Bandung ${ }^{1,2}$ )

Penerapan Finite State Automata Pada Vending Machine Penjual Obat Non Resep

Dokter Dan Keperluan Medis

Eko Supriyanto $^{1}$, Angga Ardiansyah ${ }^{2}$, Frieyadie $^{3}$, Sri Rahayu ${ }^{4}$, Windu Gata ${ }^{5}$

(Universitas Nusa Mandiri ${ }^{12}$ ) $08-14$

Sistem Pendukung Keputusan Untuk Menentukan Kelayakan Pengajuan Sertifikasi Guru Dengan Metode Simple Additive Weighting (Studi Kasus : Ma Al Muhajirin Janti Jogoroto Jombang)

Budiman, umam baharudin, winarti

(Universitas Darul 'Ulum Jombang)

Perancangan Infrastruktur Domain Name Server Lokal Menggunakan Ubuntu Server 16.04

Pada PT. Xyz

Zaenal Mutaqin Subekti, Hendra Setiawan, Satria, Widia Murni Wijaya,

Aliy Hafiz, Warsudi

(STMIK Bani Saleh, Universitas Negeri Yogyakarta, AMIK Dian Cipta Cendikia,

STMIK MIC CIkarang)

Perancangan Sistem Informasi Idea Proposal (Ip) Berbasis Web Pada Pt. Paxel Algorita Unggul

Julian Murhan Sahputra, Indah Purnamasari

(Universitas Nusa Mandiri ${ }^{12}$ )

Sistem Pendukung Keputusan Untuk Menentukan Ekstrakurikuler Atletik

Berdasarkan Bakat Siswa Menggunakan Metode Profile Matching

Agnes Basuki, Petrus Sokibi, Tiara Eka Putri

(Universitas Catur Insan Cendekia)

Penerapan Algoritma K-Means Untuk Pengelompokan Usia Calon Penerima Vaksin

Di Kab. Ngawi

Irna Yuniarfi, Saifulloh

(Universitas PGRI Madiun $^{12}$ )

System Penilaian Seleksi Calon Karyawan Baru Menggunakan Metode Simple Additive Weighting (SAW) Di PT.TNA

Anik Sri Wahyuningsih, Yudhi Firmansyah

(Universitas Panca Sakti Bekasi ) 
Perancangan Sistem Informasi Pembayaran SPP Menggunakan Framework Laravel Ichwan Habib Moudi

(Universitas Panca Sakti Bekasi)

Implementasi Algoritma K-Means Dan Algoritma Apriori Optimasi Kinerja Ecu

(Study Kasus Mobil Avanza Dan Xenia)

Sigit Mintoro' Asep Afandi

(STMIK Dian Cipta Cendikia Kotabumi)

Sistem Pakar Penyakit Buah Kakao Untuk Peningkatan Hasil Panen Kakao Menggunakan

Metode Case Base Reasoning (CBR) Berbasis Web Mobile

Aliy hafiz, Verawati

(AMIK Dian Cipta Cendikia,Bandar Lampung)

Penerapan Metode Rapid Application Develomment (RAD) Dalam Pengembangan

Sistem Pemesanan Menu Berbasis Android

Aris Baihaqi, Tumini

(Fakultas Sains dan Teknologi ${ }^{1,2}$ )

Rancang Bangun Sistem Informasi Geografis Pariwisata Di Lampung Timur

Sukatmi, Rexa Alfa Rizi

(AMIK DCC Bandar Lampung ${ }^{12}$ )

Implementasi Psak No. 45 Pada Proses Penyusunan Laporan Keuangan Menggunakan

M.S. Excel Dan Aplikasi Accurate Accouting Pada STMIK Bani Saleh

Marhakim, Willy Adam

(STMIK Bani Saleh ${ }^{12}$ )

Sistem Prediksi Harga KOPI LAMBAR ( Lampung Barat) Dengan Metode

Backpropagation, dan Double Exponential ( Studi Kasus BUMDES )

Supriyanto, Dwi marisa Efendi,Rhomadhon

(STMIK Dian Cipta cendikia Kotabumi ${ }^{1-}$ )

Sistem Informasi Pemasaran Produk Umkm Berbasis Web Pada Kecamatan Bumi

Nabung Lampung Tengah

Yuli Syafitri, Agus Prasetyo, Reni Astika

(AMIK Dian Cipta Cendikia Bandar Lampung)

Rancang Bangun Aplikasi Pembelajaran Aksara Lampung Berbasis Android

Ferly Ardhy, Hendra Syahrobi

(Universitas Aisyah Pringewu ${ }^{1,}$ STMIK Dian Cipta Cendikia ${ }^{2}$ )

Sistem Pakar Diagnosa Penyakit Kulit Pada Balita Menggunakan Metode Naïve

Bayes Dan Forward Chaining Studi Kasus Puskesmas Cempaka Sungkai Selatan

Sidik Rahmatullah, Rima Mawarni

(STMIK Dian Cipta Cendikia Kotabumi ${ }^{12}$ )

Rekayasa Perangkat Lunak Perhitungan Harga Pokok Produksi Metode

Full Costing Pada Umkm Mitra Cake Di Bandar Lampung

Pitrawati, Arif Sanjaya

(AMIK Dian Cipta Cendikia, Bandar Lampung) 
Rancang Bangun Sistem Ujian Online Menggunakan Algoritma Cosine Similarity

Berbasis Web

Haryono, Zaenal Mutaqin Subekti, Widiyawati, Hidayatullah

(STMIK Bani Saleh ${ }^{1234}$ )

Model Aplikasi Helpdesk Ticketing System Berbasis Web Menggunakan Metode Rad

Indra Permana

Pattern Recognition Tulisan Tangan Huruf Hijaiyah Menggunakan Metode

Convolutional Neural Network (CNN)

Mufassiril Abror, Nopiyanto

(Universitas Panca Sakti Bekasi ${ }^{12}$ )

Aplikasi Sistem Informasi Keuangan Berbasis Android Di Perumahan Taman

Karang Bahagia

Melda Ayulestari

(Universitas Panca Sakti Bekasi)

Audit Pelayanan Sistem Rujukan Online Puskesmas Menggunakan Framework COBIT 5.0

Nurmayanti, Merri Parida, Ngajiyanto, Ina Anzalna

(STMIK Dian Cipta Cendikia Kotabumi ${ }^{1234}$ )

Perancangan Sistem Informasi Pengolahan Data Nilai Siswa Berbasis Web

Erin Ermawati, Anik Sri Wahyuningsih

(Fakultas Sain dan Teknologi, Universitas Panca Sakti Bekasi ${ }^{12}$ )

Pengembangan Sistem Pelaporan Data Hasil Inspeksi Barang Berbasis Web

Siska Putriani

(Universitas Pancasakti Bekasi)

Penerapan Extreme Programming Dalam Perancangan Aplikasi Web Food Market

Tumini, Hilman Septiana

(Fakultas Sains dan Teknologi Universitas Panca Sakti Bekasi ${ }^{1,2}$ )

Sistem Pencarian Barang Berbasis Website Menggunakan Php Dan Mysql

Studi Kasus PT. Surya Technology Industri Sulaeman

(Universitas Panca Sakti Bekasi)

Implementasi Metode Prototype Pada Sistem Peminjaman Alat Kerja Berbasis Web

Di PT SK Metalindo

Ali Mulyanto, Arjun Gunawan

(Univeritas Panca Sakti Bekasi)

Aplikasi Tata Cara Wudhu Menggunakan Teknologi Augmented Reality

Sebagai Media Pembelajaran Di TK Al Fatih

Ahmad Yakub , Idarul Fadli

(Universitas Panca Sakti Bekasi ${ }^{12}$ )

Sistem Pakar Diagnosa Penyakit Ayam Petelur Menggunakan Metode Certainty Factor

Berbasis Web Mochammad

Taufiq Hidayat, Ali Mulyanto

(Universitas Panca Sakti Bekasi ${ }^{12}$ ) 
Penerapan Metode Prototyping Dalam Perhitungan Hasil Produksi Menggunakan

Arduino Uno R3 Dan Php Di PT. Indonesia Epson Industry

Amandha Aulia, Ajar Rohmanu

(Universitas Panca Sakti Bekasi ${ }^{12}$ )

System Pendukung Keputusan Penentuan Guru Teladan Dengan Metode Profile Matching

Hasbulloh, Agmawarnida

(Universitas Panca Sakti Bekasi ${ }^{1,2}$ )

Implementasi Waterfall Method Pada Aplikasi Buku Induk Siswa Berbasis Web

Idam Holid, Yogie Krisnayadi

(Universitas Panca Sakti ${ }^{12}$ )

Pengembangan Text To Speech Media Pembelajaran Untuk Pengenalan

Anggota Tubuh Manusia Kelas V Sekolah Dasar

Juwanda Saputra, Ali Mulianto

(Teknik Infomratika Fakulutas Sains dan Teknologi ${ }^{12}$ )

Perancangan Sistem Peminjaman Barang Berupa Aset Tetap Berbasis Web

Pada Lembaga Permasyarakatan Kelas II A Banceuy Bandung

Guntur Salasa Priambodo, Perwito, Candra Mecca Sufyana

(Politeknik Piksi Ganesha Bandung ${ }^{1,2,3}$ )

Metode Pemilihan Karyawan Terbaik Sebagai Penentu Goodwill Perguruan Tinggi

Dengan Menggunakan Metode Topsis (Studi Kasus Perguruan Tinggi Di Lampung Utara)

Dwi Sartika, Pakarti Riswanto

(STMIK Dian Cipta Cendikia Kotabumi)

Sistem Pendukung Keputusan Pemilihan Merek Smartphone Menggunakan

Metode Analytical Hierarchy Process (AHP)

Ade Kiki Fatmawati, Muhammad Sultan Raflie, Norma Yunita

(Universitas Nusa Mandiri ${ }^{123}$ )

Pattern Recognition Aksara Lampung Menggunakan Algoritma Neural Network

Metode Analytical Hierarchy Process (AHP)

Nopiyanto, Rahmadi

(Universitas Panca Sakti Bekasi) 


\title{
PENERAPAN METODE PROTOTYPING DALAM PERHITUNGAN HASIL PRODUKSI MENGGUNAKAN ARDUINO UNO R3 DAN PHP DI PT. INDONESIA EPSON INDUSTRY
}

\author{
Amandha Aulia ${ }^{1}$, Ajar Rohmanu $^{2}$ \\ Universitas Panca Sakti Bekasi ${ }^{12}$ \\ Jl. Kapten Sumantri No.16, Cikarang Utara, Bekasi, Jawa Barat 17530 \\ E-mail : amandhaaulia4@gmail.com
}

\begin{abstract}
ABSTRAK
Era revolusi industri 4.0 atau revolusi industri dunia ke-empat telah berjalan seiring berjalannya waktu, dimana teknologi telah menjadi basis dalam kehidupan manusia. Setiap hal menjadi tanpa batas dan tidak terbatas akibat perkembangan teknologi digital. Era ini mempengaruhi banyak aspek kehidupan baik di bidang ekonomi, politik, kebudayaan, pendidikan dan industri. Industri merupakan salah satu tempat teknologi yang berguna untuk membantu berjalannya industri di perusahaan. PT Indonesia Epson Industry yang berlokasi di Kawasan East Jakarta Industrial Park (EJIP) Cikarang Bekasi merupakan salah satu perusahaan yang memproduksi berbagai macam barang elektronik. Produksi merupakan hal yang terpenting dalam proses pembuatan produk dari proses awal hingga akhir proses produk, perhitungan hasil produksi sangatlah penting untuk mengetahui hasil produktifitas dari proses hingga ke finish good. PT Indonesia Epson Industry dalam perhitungan hasil produksi masih menerapkan sistem manual dalam perhitungan dengan menambah pekerjaan karyawan yaitu dengan operator produksi melakukan packing produk sekaligus menghitung barang dan mencatat hasil jumlah produksi barang dan memerlukan waktu untuk admin produksi mengetahui hasil produksi yang real time. penulis dalam hal ini membuat suatu sistem yang bertujuan untuk menampilkan jumlah produk yang di produksi langsung ke bagian admin dengan menggunakan alat arduino, sensor ultrasonic, Ethernet Shield dan program menggunakan bahasa pemrograman php kemudian menggunakan database mysql yang terhubung dengan XAMPP agar dapat menjadikan aplikasi sistem yang berguna untuk menampilkan jumlah barang secara langsung tanpa harus menunggu lama. Penulis juga menggunakan metode prototyping untuk menjadikan sistem yang dibuat sesuai apa yang dibutuhkan oleh perusahaan dan yang direncanakan. diharapkan dengan adanya sistem ini tidak ada lagi kekeliruan dalam perhitungan dan pekerjaan menjadi lebih efisien dan mudah serta sistem ini diharapkan dapat di pergunakan dalam jangka panjang.
\end{abstract}

Kata kunci : Arduino Uno R3, Metode Prototyping, Perhitungan Hasil Produksi

\begin{abstract}
S
The era of the industrial revolution 4.0 or the fourth world industrial revolution has gone by over time, where technology has become the basis of human life. Everything becomes limitless and unlimited due to the development of digital technology. This era affects many aspects of life in the fields of economy, politics, culture, education and industry. Industry is one of the places where technology is useful to help run the industry in the company. PT Indonesia Epson Industry, which is located in the East Jakarta Industrial Park (EJIP) Cikarang Bekasi area, is a company that produces various kinds of electronic goods. Production is the most important thing in the process of making products from the beginning to the end of the product process, the calculation of production results is very important to know the productivity results from the process to the finish good. PT Indonesia Epson Industry in calculating production results still applies a manual system in calculations by adding employee work, namely with production operators doing product packing while counting goods and recording the results of the production of goods and it takes time for the production admin to know real time production results. the author in this case makes a system that aims to display the number of products produced directly to the admin section using Arduino, ultrasonic sensors, Ethernet Shield and programmed using the PHP programming language then using a MySQL database connected to XAMPP in order to make system applications which is useful for displaying the number of items directly without having to wait long. The
\end{abstract}


author also uses the prototyping method to make the system that is made according to what is needed by the company and what is planned. it is hoped that with this system there will be no more errors in calculations and work will be more efficient and easy and this system is expected to be used in the long term.

Keywords: Arduino Uno R3, Prototyping Method, Calculation of Production Results

\section{PENDAhUluan}

Era revolusi industri 4.0 telah menjadi basis dalam kehidupan manusia. Industri merupakan salah tempat untuk teknologi yang berguna untuk membantu berjalanya industri di perusahaan.

PT Indonesia Epson Industry yang berlokasi di Kawasan Industri East Jakarta Industrial Park (EJIP) Cikarang Bekasi, merupakan salah satu perusahaan yang memproduksi berbagai macam barang elektronik. Produk merk EPSON sendiri sudah dikenal banyak orang di Indonesia maupun dunia bergerak pada bidang printer, PT Indonesia Epson Industry berdiri pada oktober tahun 2000 di indonesia. Produksi merupakan hal yang terpenting dalam proses pembuatan barang-barang dari proses awal hingga akhir proses barang, perhitungan hasil produksi

Indonesia Epson Industri dalam perhitungan hasil produksi masih menerapkan sistem manual dalam perhitungan dengan menambah pekerjaan karyawan yaitu dengan operator produksi melakukan packing barang sekaligus menghitung barang dan mencatat hasil jumlah produksi barang dan memerlukan waktu banyak untuk admin produksi mengetahui hasil barang yang real time.

Berdasarkan dari latar belakang di atas perlu adanya pengembangan dalam sistem perhitungan dalam hasil produksi dan penulis dapat memberikan solusi dari masalah tersebut yang dibuat sebagai judul penelitian bersama yaitu Penerapan Metode Prototyping dalam Perhitungan Hasil Produksi Menggunakan Arduino Uno R3 dan Php di PT. Indonesia Epson Industry.

\section{LANDASAN TEORI}

\subsection{Metode Prototyping}

Menurut Somemeville, (2011), prototype adalah versi awal dari sistem perangkat lunak yang digunakan untuk mendemonstrasikan konsepkonsep, percobaan rancangan, dan menemukan lebih banyak masalah dan solusi yang memungkinkan" [1].

Model Prototyping digunakan untuk merancang sistem informasi. Model prototype memberikan kesempatan untuk pengembang program dan objek penelitian untuk saling berinteraksi selama proses perancangan sistem [2].

\subsection{Pengujian Sistem Black Box Testing}

Pengujian perangkat lunak dari segi spesifikasi fungsional tanpa menguji desain dan kode program untuk mengetahui apakah fungsi, masukan dan keluaran dari perangkat lunak sesuai dengan spesifikasi yang dibutuhkan[3].

\subsection{Produksi}

Produksi adalah suatu proses dimana barang dan jasa yang disebut input diubah menjadi barangbarang dan jasa-jasa yang disebut output.Proses perubahan bentuk faktor-faktor produksi tersebut disebut dengan proses produksi [4]

\subsection{Arduino Uno R3}

Arduino Uno R3 merupakan salah satu Arduino yang murah, mudah didapat, dan sering digunakan. Arduino Uno ini dibekali dengan mikrokontroler ATMEGA328P dan versi terakhir yang dibuat adalah versi R3[5]

Modul ini sudah dilengkapi dengan berbagai hal yang dibutuhkan untuk mendukung mikrokontroler untuk bekerja. ATMega328P yang sudah terbentuk modul Arduino uno seperti terlihat pada gambar di bawah ini.

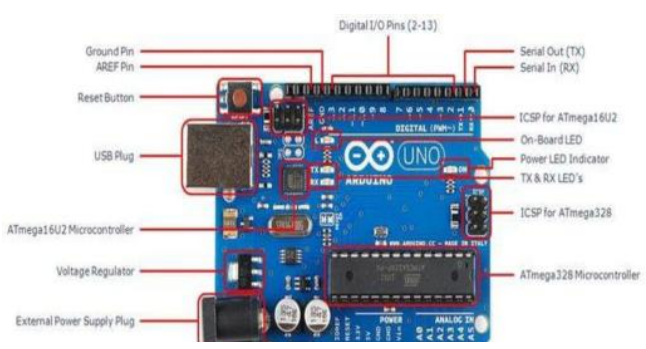

Gambar 2.1 Arduino Uno R3 


\subsection{Sensor Ultrasonic}

"Sensor ultrasonik terdiri dari dari dua unit, yaitu unit pemancar dan unit penerima struktur unit pemancar dan penerima. Sangatlah sederhana sebuah kristal piezoelectric dihubungkan dengan mekanik jangkar dan hanya dihubungkan dengan diafragma penggetar tegangan bolak-balik yang memiliki frekuensi kerja 20 kHz hingga 2 MHz”[6]

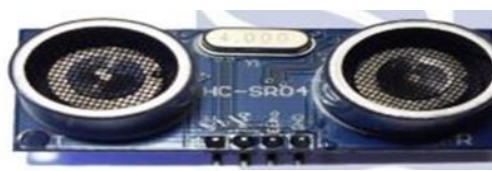

Gamabr 2.2 Sensor Ultrasonic HCRF 4

\subsection{Ethernet Shield}

Arduino Ethernet Shield ini menggunakan chip WIZnet W5100 Ethernet Chip, yang dapat memberi kemudahan untuk membuat aplikasi online (terhubung dengan internet). Shield ini telah didukung oleh library Arduino. W5100 WIZnet mendukung hingga empat koneksi soket secara simultan.[7]

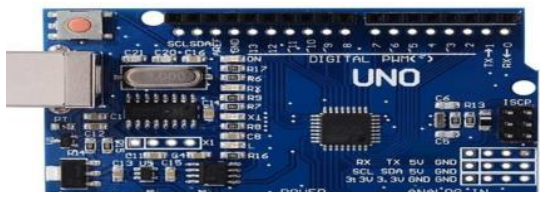

Gambar 2.3 Ethernet Shield

\subsection{Hypertext Preprocessor ( Php)}

Hypertext preprocessor (PHP) merupakan bahasa pemrograman untuk pembuatan website dinamis, yang mampu berinteraksi dengan pengunjung atau penggunanya[8].

\subsection{My Struktur Query Language (MySQL)}

MySQL adalah sistem manajemen database SQL yang sifatnya open source (terbuka) dan paling banyak digunakan saat ini. Sistem database MySQL mampu mendukung beberapa fitur seperti multithreaded, multi-user, dan SQL database management system (DBMS). Apabila kita membutuhkan sistem database yang cepat, andal, dan mudah digunakan segera kita gunakan sebuah implementsai dari sistem manajemen data relasional (RDBMS) yang didistribusikan secara gratis [9].

\subsection{XАMPP}

XAMPP merupakan sebuah software web server apache yang didalamnya sudah tersedia database server MySQL dan support php programming. XAMPP merupakan software yang mudah digunakan, gratis dan mendukung instalasi di linux dan windows. [10].

\subsection{Unified Modeling Language (UML)}

"Unified Modeling Language (UML) adalah Salah standar bahasa yang banyakdigunakan di dunia industri untuk mendefinisikan requerement, membuat analisa \& desain, serta menggambarkan arsitektur dalam pemrograman berorintasi objek [11].

\section{METODELOGI PENELITIAN}

\subsection{Metode Pengembangan Sistem}

Pembuatan sistem dengan menggunakan metode

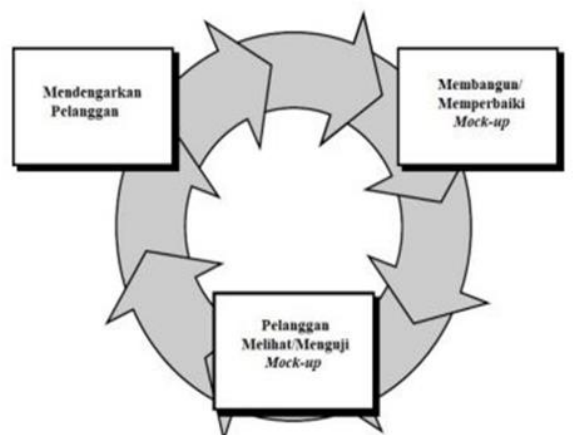

Gambar 3.1 Metode Prototype

Tahapan prototype yaitu

\section{a.Mendengarkan Pelanggan}

Pengembang program dan objek penelitian bertemu dan menentukan tujuan.

\section{b. Membangun atau Memperbaiki Mock-Up}

Perancangan sistem dapat dikerjaan apabila data-data yang berkaitan telahdikumpulkan selama pengumpulan kebutuhan.

\section{c. Pelanggan Melihat dan Menguji Mock-Up}

Objek penelitian mengevaluasi prototype yang dibuat dan dipergunakan untuk memperjelas kebutuhan software 


\subsection{Pengumpulan Kebutuhan}

Penulis melakukan pengumpulan data-data dari tahap pertama hingga ke dua kemudian penulis mengolah data-data dari masalah serta melakukan studi pustaka kemudian dari hasil tersebut penulis memilih metode yang tepat yaitu metode prototyping.

\section{Desain Sistem}

Dalam Tahapan proses ini yaitu pembuatan rancangan secara meneyluruh untuk tahap selanjtunya dikembangkan kembali. Pada tahap ini proses perancangan dilakukan dengan menggunakan dengan penggambaran diagram dan perancangan Alat .Diagram dan perancangan alat yang dimaksud antra lain adalah Use Case Diagram, Activity Diagram,Sequence Diagram, Class Diagram serta perancangan alat untuk sistem perhitungan berikut ini adalah tahapan perancanganya.

\section{a. Use Case Diagram Sistem Usulan}

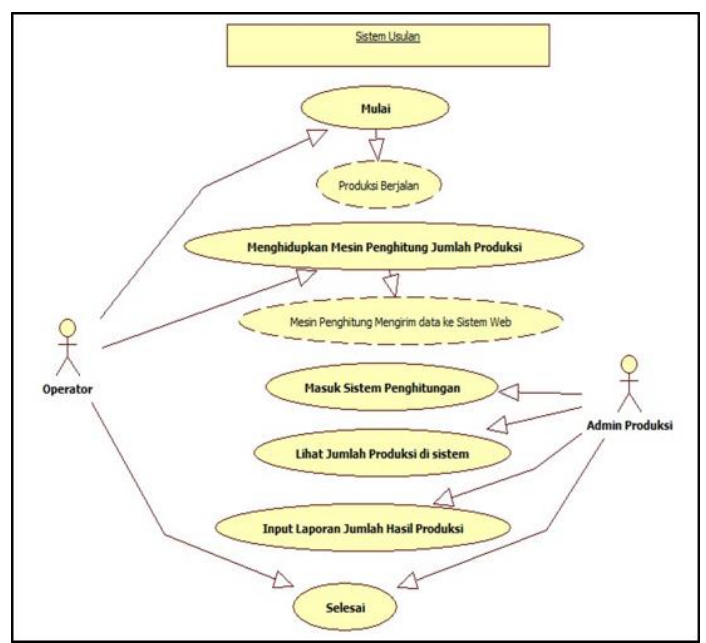

Gambar 3.2 Use Case Sistem Usulan

\section{b. Activity Diagram Login}

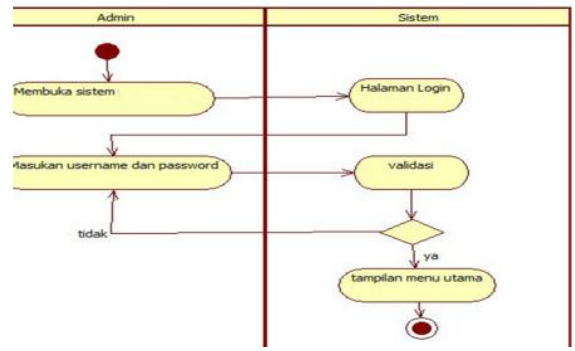

Gambar 3.3 Activity Diagram Login

c. Activity Diagram Sistem Perhitungan

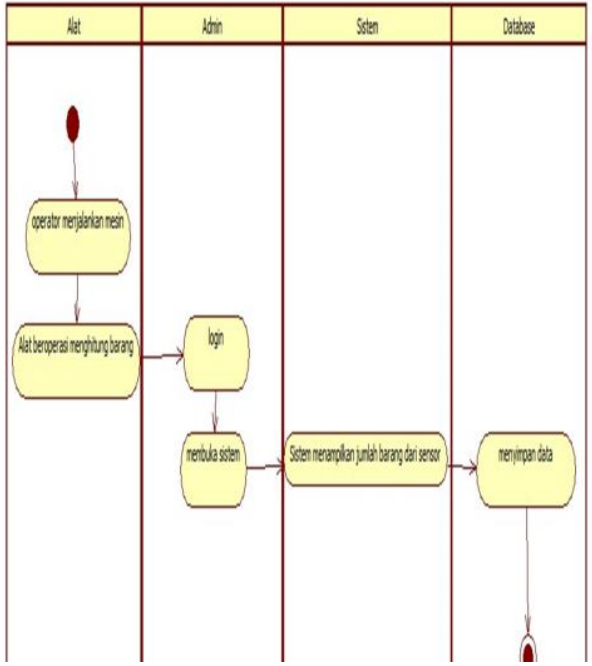

Gambar 3.3 Activity Diagram Sistem Perhitungan

\section{d. Sequence Diagram Login}

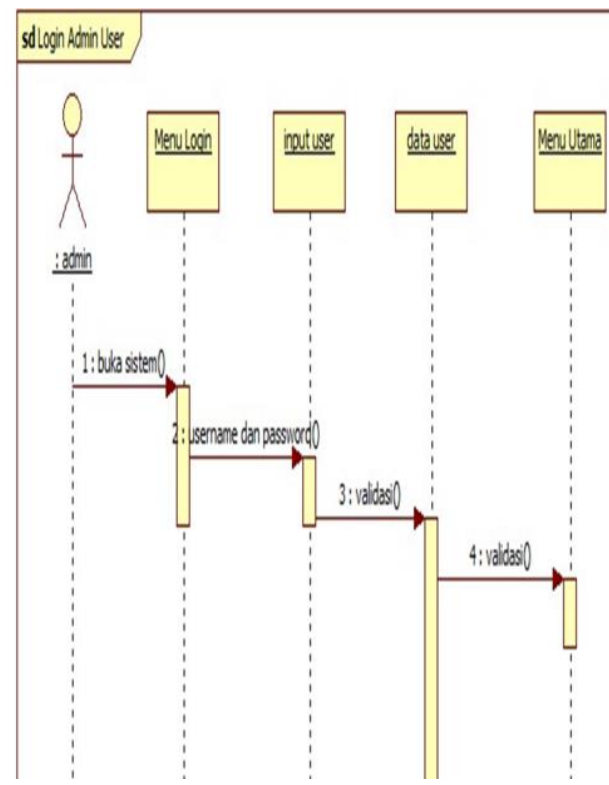

Gambar 3.4 Sequence Diagram Login 
e. Sequence Diagram Sistem Perhitungan

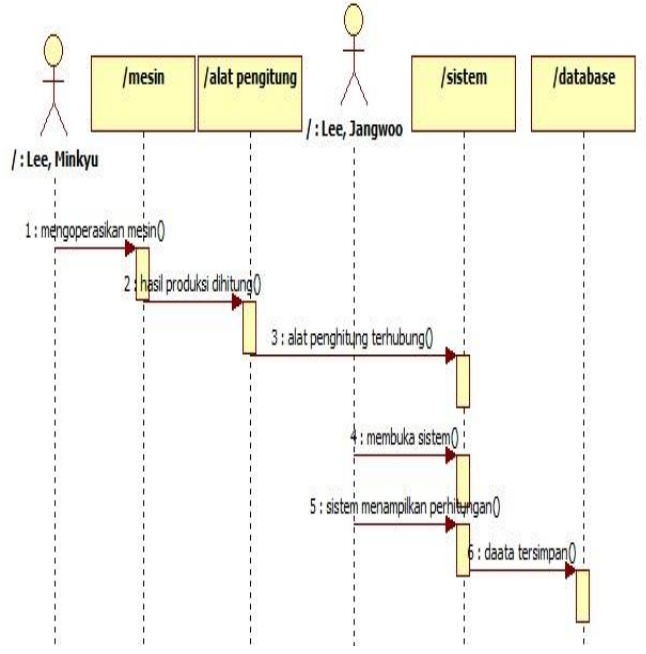

Gambar 3.5 Sequence Diagram Sistem Perhitungan

\section{f. Class Diagram}

\begin{tabular}{|l|l|}
\hline \multicolumn{1}{|c|}{ Admin } & \multicolumn{2}{c|}{ Sensor } \\
\cline { 1 - 1 } $\begin{array}{l}\text { +Username } \\
\text { +Password }\end{array}$ & $\begin{array}{l}\text { +no } \\
\text { +Jumlah } \\
\text { +Waktu } \\
+\end{array}$ \\
\hline $\begin{array}{l}\text { +input0 } \\
\text { +update0 } \\
\text { +delete0 }\end{array}$ & $\begin{array}{l}\text { +input0 } \\
\text { +update0 }\end{array}$ \\
\hline
\end{tabular}

Gambar 3.6 Class Diagram

\section{g. Perancangan Alat}

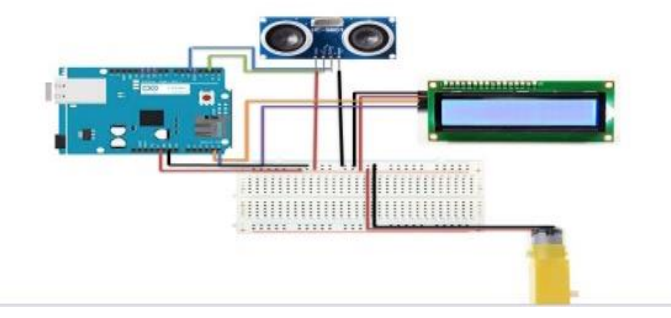

Gambar 3.7 Rangkaian Alat

\section{HASIL DAN PEMBAHASAN}

Pada tahap ini akan menerangkan hasil dari rancangan yang telah di di tulis di bab 3 yang berupa implementasi dan pembahasan dengan pengujian sistem dengan pengujian sistem menggunakan pengujian black box dan kuesioner.

\subsection{Implementasi alat perhitungan}

Alat perhitungan di rangkai dengan beberapa alat mikrokontroler yaitu

1. Arduino Uno R3

2. LCD I2C

3. Sensor Ultrasonic

4. Motor Dc 5volt

5. Ethernet Shield

Berikut ini adalah hasil implementasi dari rangkaian yang di kemukakan di bab 3 .

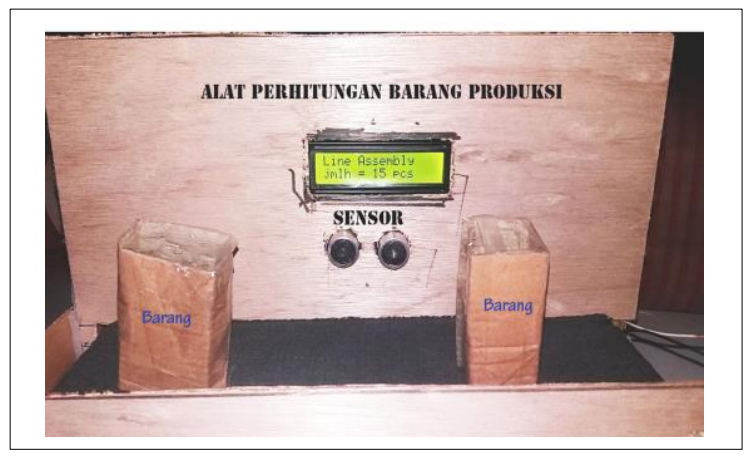

Gambar 4.1 Implentasi Alat

\section{a. Penjelasan}

Terlihat bahwa conveyor yang di rangkai mengguanakan motor dc 5volt bergerak membawa produk dan akan terdeteksi oleh sensor ultrasonic.

Sensor ultasonic dapat mendeteksi produk dengan jarak maksimal $10 \mathrm{~cm}$. Kemudian mengirim data melalui Arduino Uno R3 kemudian hasil data di tampilkan dengan LCD dan di Sistem.

Tampilan dalam sistem nya yaitu.

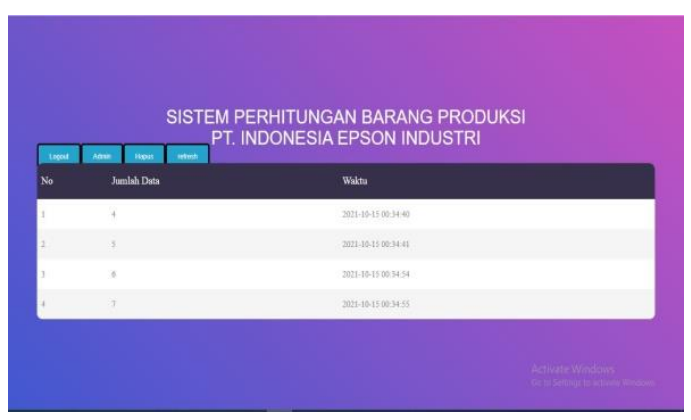

Gambar 4.2 Menampilkan perhitungan dengan sistem 


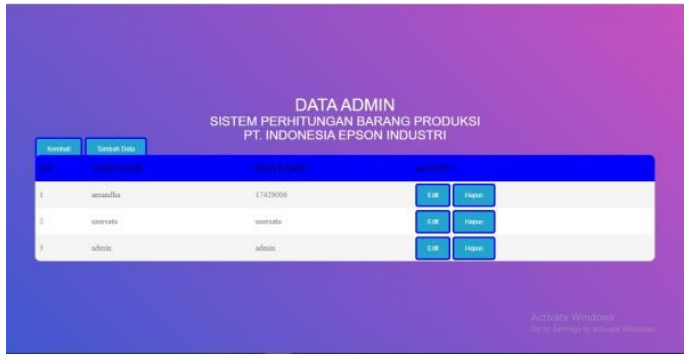

Gambar 4.3 Menampilkan Data Dengan Sistem

Sistem menampilkan hasil sensor yang data di terima dari arduino Uno R3 dan ethernet shield yang terhubung ke database MySQL tugas sistem yang di program menggunakan bahasa pemrograman Php ialah menampilkan data perhitungan.

\subsection{Pengujian Sistem}

Pengujian dilakukan untuk mengetahui apakah sistem perhitungan hasil produksi menggunakan arduino uno R3 dan php di PT. Indonesia Epson Industry telah sesuai dengan rancangan.

Dengan melakukan pengujian, maka dapat diketahui apakah program yang telah dibuat sudah berjalan dengan baik atau belum, pengujian yang digunakan adalah metode pengujian black box.

\section{a. Verifikasi Kinerja Sistem}

Pengujian perangkat lunak ini menggunakan metode pengujian blackbox. Pengujian blackbox berfokus pada persyaratan fungsional perangkat lunak yang dibuat.

\section{Tabel Rancangan}

Tabel 4.1 Tabel Rancangan Pengujian

\begin{tabular}{|l|l|l|}
\hline \multicolumn{3}{|c|}{ Rancangan Pengujian } \\
\hline Kelas Uji & \multicolumn{1}{|c|}{ Detail Pengujian } & Jenis Pengujian \\
\hline Menu Login & $\begin{array}{l}\text { Verifikasi data Login } \\
\text { dan Hak Akses Login }\end{array}$ & Black Box \\
\hline $\begin{array}{l}\text { Menu } \\
\text { Tampilan }\end{array}$ & $\begin{array}{l}\text { Verifikasi Fungsi } \\
\text { membaca data sensor } \\
\text { logout, data admin } \\
\text { refresh dan hapus }\end{array}$ & Black Box \\
\hline $\begin{array}{l}\text { Sensor } \\
\text { Ultrasonic }\end{array}$ & mendeteksi barang & black Box \\
\hline
\end{tabular}

\section{Hasil Pengujian}

Tabel 4.2 Tabel Pengujian Login

\begin{tabular}{|c|c|c|c|c|}
\hline No & Skenario & Bagian di Uji & $\begin{array}{l}\text { Prosedur } \\
\text { Pengujian }\end{array}$ & $\begin{array}{l}\text { Hasil } \\
\text { Pengujian }\end{array}$ \\
\hline 1 & $\begin{array}{c}\text { username dan } \\
\text { password tidak } \\
\text { di isi }\end{array}$ & $\begin{array}{c}\text { user name dan } \\
\text { password tidak diisi }\end{array}$ & $\begin{array}{c}\text { Sistem } \\
\text { tidak } \\
\text { Menerima } \\
\text { login } \\
\text { dengan } \\
\text { password } \\
\text { kosong }\end{array}$ & Berhasil \\
\hline 2 & $\begin{array}{l}\text { username dan } \\
\text { password di isi }\end{array}$ & $\begin{array}{l}\text { username : admin } \\
\text { password : admin }\end{array}$ & $\begin{array}{c}\text { sistem } \\
\text { menerima } \\
\text { pasword } \\
\text { dan } \\
\text { username } \\
\text { yang telah } \\
\text { terdaftar }\end{array}$ & Berhasil \\
\hline
\end{tabular}

Tabel 4.3 Tabel pengujian Menu tampilan

\begin{tabular}{|c|c|c|c|c|}
\hline $\begin{array}{l}\mathrm{N} \\
\mathrm{O}\end{array}$ & Skenario & $\begin{array}{l}\text { Bagian } \\
\text { di Uji }\end{array}$ & $\begin{array}{l}\text { Prosedu } \\
\text { r } \\
\text { Penguji } \\
\text { an }\end{array}$ & $\begin{array}{l}\text { Hasil } \\
\text { Pengujia } \\
n\end{array}$ \\
\hline 1 & $\begin{array}{l}\text { Menamp } \\
\text { ilkan } \\
\text { data } \\
\text { barang }\end{array}$ & $\begin{array}{l}\text { Sistem } \\
\text { penamp } \\
\text { ilan } \\
\text { data }\end{array}$ & $\begin{array}{l}\text { Data } \\
\text { ditampi } \\
\text { lkan }\end{array}$ & Berhasil \\
\hline 2 & $\begin{array}{l}\text { Klik } \\
\text { Logout }\end{array}$ & $\begin{array}{l}\text { Tampil } \\
\text { an } \\
\text { Logout }\end{array}$ & $\begin{array}{l}\text { Berhasi } \\
\text { 1 Keluar } \\
\text { sistem }\end{array}$ & Berhasil \\
\hline 3 & $\begin{array}{l}\text { Klik } \\
\text { Admin }\end{array}$ & $\begin{array}{l}\text { Tampil } \\
\text { an Data } \\
\text { Admin }\end{array}$ & $\begin{array}{l}\text { Menam } \\
\text { pilkan } \\
\text { Data } \\
\text { Admin } \\
\text { besrta }\end{array}$ & Berhasil \\
\hline 4 & $\begin{array}{c}\text { Klik } \\
\text { Refresh }\end{array}$ & $\begin{array}{c}\text { Tampil } \\
\text { an } \\
\text { Refresh }\end{array}$ & $\begin{array}{c}\text { Menam } \\
\text { pilkan } \\
\text { refres } \\
\text { data }\end{array}$ & Berhasil \\
\hline 5 & $\begin{array}{c}\text { Klik } \\
\text { Hapus }\end{array}$ & $\begin{array}{c}\text { Tampil } \\
\text { an } \\
\text { Hapus }\end{array}$ & $\begin{array}{c}\text { Akan } \\
\text { Mengh } \\
\text { apus } \\
\text { data }\end{array}$ & Berhasil \\
\hline
\end{tabular}

Tabel 4.4Tabel Pengujian Sensor Ultrasonic 


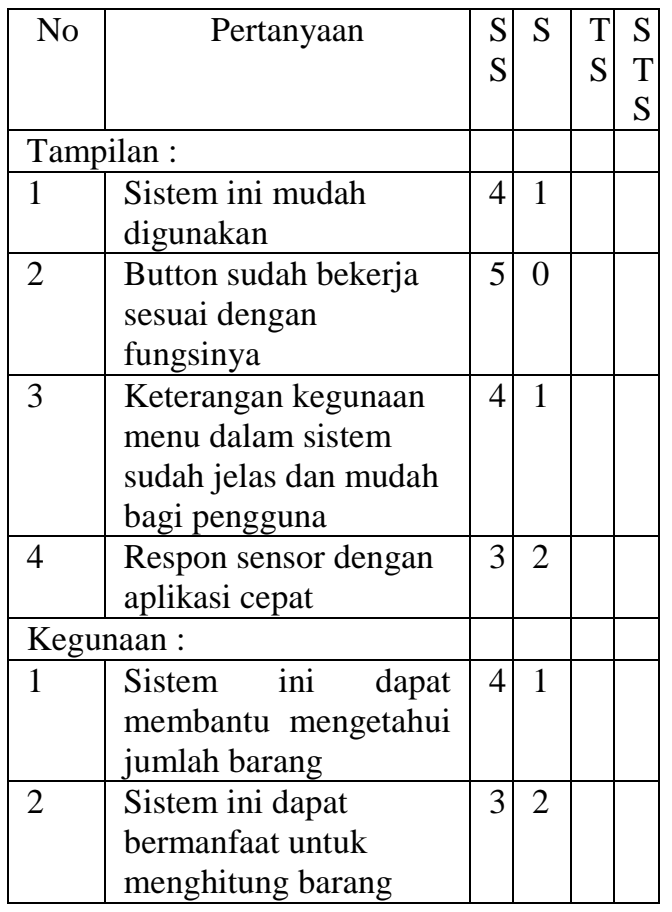

\section{b. Validasi Pengujian Sistem}

Dalam pengujian kelayakan sistem ini penulis menggunakan tahapan uji kelayakan kuesioner. Kuesioner merupakan daftar pertanyaan yang diajukan kepada responden untuk mencari jawaban dari permasalahan yang teliti.

Berdasarkan batasan masalah, penerapan metode prototyping dalam sistem perhitungan hasil produksi menggunakan arduino uno R3 di PT. Indonesia Epson Industry yang sesuai dengan target dari aplikasi tersebut setelah mencoba, mereka menjawab kuesioner untuk mengetahui presentase keberhasilan dari sistem ini.

Keterangan

1. $\quad$ SS $=$ sangat setuju $=4$

2. $\mathrm{S}=$ setuju $=3$

3. $\mathrm{TS}=$ tidak setuju $=2$

4. $\quad$ STS $=$ sangat tidak setuju $=1$

5. $\quad \mathrm{Y}=$ Skor tertinggi likert $\mathrm{x}$ jumlah responden (Angka Tertinggi 5) "perhatikan bobot nilai"

F6 $\quad \mathrm{X}=$ Skor terendah likert $\mathrm{x}$ jumlah responden (Angka terendah 1) "perhatikan bobot nilai"

Rumus index \% = total skor $/ \mathrm{Y}$ x 100.

\begin{tabular}{|c|c|c|c|l|}
\hline No & Skenario & Bagian di Uji & $\begin{array}{c}\text { Prosedur } \\
\text { Pengujian }\end{array}$ & $\begin{array}{l}\text { Hasil } \\
\text { Pengujian }\end{array}$ \\
\hline 1 & $\begin{array}{c}\text { jarak barang 5 } \\
\mathrm{cm}\end{array}$ & $\begin{array}{c}\text { menguji jarak sensor } \\
\text { dengan } 5 \mathrm{~cm}\end{array}$ & $\begin{array}{c}\text { sensor } \\
\text { mendeteks } \\
\text { i barang }\end{array}$ & Berhasil \\
\hline 2 & $\begin{array}{c}\text { jarak barang 10 } \\
\mathrm{cm}\end{array}$ & $\begin{array}{c}\text { menguji jarak sensor } \\
\text { dengan jarak 10 cm }\end{array}$ & $\begin{array}{c}\text { sensor } \\
\text { mendeteks } \\
\text { i barang }\end{array}$ & Berhasil \\
\hline 3 & $\begin{array}{c}\text { jarak barang 11 } \\
\mathrm{cm}\end{array}$ & $\begin{array}{c}\text { menguji jarak sensor } \\
11 \mathrm{~cm}\end{array}$ & $\begin{array}{c}\text { tidak } \\
\text { mendeteks } \\
\text { i }\end{array}$ & berhasil \\
\hline
\end{tabular}

Tabel 4.5Lembar kuesioner untuk user

Hasil perhitungan jawaban responden sebagai berikut :

1) Responden yang menjawab sangat setuju $(23)=23 \times 4=92$

2) Responden yang menjawab setuju (6) $=6 x$ $3=18$

3) Responden yang menjawab tidak setuju (0) $=0 \times 2=0$

4) Responden tidak sangat setuju $(0)=0 \times 1=$ 0

$$
\text { Total Skor }=92+18+0+0=110
$$

Untuk mendapatkan hasil interpretasi, harus diketahui dulu skor tertinggi $(X)$ dan angka terendah $(\mathrm{Y})$ untuk item penilaian dengan rumus sebagai berikut :

$\mathrm{Y}=$ Skor tertinggi likert $\mathrm{x}$ jumlah responden (Angka Tertinggi 23) "Perhatikan Bobot Nilai"

$\mathrm{X}=$ Skor terendah likert $\mathrm{x}$ jumlah responden (Angka Terendah 18) "Perhatikan Bobot Nilai"

Jumlah skor tertinggi untuk item SANGAT SETUJU ialah $23 \times 5=115$, sedangkan item SETUJU ialah $6 \times 5=30$. Jadi, jika total skor responden di peroleh angka 110, maka penilaian interpretasi responden terhadap media pembelajaran tersebut adalah hasil nilai yang dihasilkan dengan menggunakan rumus Index $\%$.

Rumus Index \% = Total Skor $/ \mathrm{Y}$ x 100

Maka penyelesaian akhir dari contoh kasus :

$=$ Total Skor $/$ Y x 100

$=110 / 115 \times 100$

$=95,6 \%=95 \%$ Kategori Sangat (Setuju, Baik, Suka)

Dari hasil di atas maka dapat disimpulkan bahwa responden sangat (setuju,baik,suka) untuk perhitungan barang otomatis dengan arduino uno R3 dan sistem yang memunculkan jumlah perhitungan barang. 


\section{c. Hasil Pengujian Penerapan Sistem}

dalam pembahasan tersebut diantaranya ialah

a. Operator produksi mengluhkan tentang kurang fokus terhadap menghitungan barang kemudian melakukan rakit barang serta cek produk sehingga terjadi kesalahan dalam perhitungan dan juga barang yang rusak atau tidak bagus sering tidak terdeteksi kemudian membuat laporan.

b. Supervisior dan leader masih mendapati produk rusak yang tidak terdeteksi dan jumlah produk yang tidak sesuai aktual

c. admin produksi harus cek jumlah aktual produk sebelum input ke sistem.

d. HRD sering menerima laporan terhadap produktifitas operator produksi. Dari hasil pembahasan masalah tersebut penulis mengajukan sistem perhitungan produk dengan menggunakan Arduino Uno R3 dalam menghitung barang kemudian sistem yang muncul di motnitor admin melalui localhost dengan metode prototyping.

Dari pengajuan sistem tersebut telah disetujui oleh Operator Produksi, Supervisior, Ledaer, Admin Produksi dan HRD.

1. Membangun atau Memperbaiki Mock-Up Penulis membangun sistem dengan Alat Arduino Uno R3 , Sensor Ultrasonic sebagai sensor pendeteksi barang, Ethernet shield berguna unutk penghubung data Arduino Uno R3 ke sistem, sistem yang dibuat dengan menggunakan pemrograman Php dengan database MySQL yang berguna untuk memunculkan data dari Arduino Uno R3.

2. Pelanggan Melihat dan Menguji Mock-Up Pengujian menggunakan metode black box dimana metode tersebut menguji tamilan serta fungsi dari sistem tersebut pelanggan telah menguji sistem tersebut yaitu diantaranya Operator Produksi, Supervisior, Leader, Admin Produksi dan HRD kemudian dari hasil kuesioner mendapatkan hasil yaitu 95,6\% = 95\% Kategori Sangat (Setuju, Baik, Suka).

Dari hasil di atas maka dapat disimpulkan bahwa responden sangat (setuju,baik,suka) untuk perhitungan barang otomatis dengan arduino uno R3 dan sistem yang memunculkan jumlah perhitungan hasil produksi.

\section{KESIMPULAN DAN SARAN}

\subsection{Kesimpulan}

Sesuai dengan uraian-uraian serta hasil analisis dan interprestasi data yang telah dijelaskan sebelumnya, maka dapat diambil beberapa kesimpulan yaitu :

1. Arduino Uno R3, Ethernet Shield dan Sensor Ultrasonic dapat berfungsi untuk menghitung barang dengan tepat sehingga dapat mengurangi beban operator produksi.

2. Sistem perhitungan yang di tampilkan dengan sistem web menggunakan localhost yang dibuat menggunakan bahasa pemrograman Php dapat memudahkan Admin Produksi dalam melihat jumlah produksi tanpa mengecek actual produk.

\subsection{Saran}

Berdasarkan kesmipulan dan analisa yang telah dilakukan serta untuk pengembangan lebih lanjut, maka penulis berharap kedepanya sistem yang telah dibuat saat ini dapat dikembangkan dengan lebih baik lagi dan dapat dikembangakan sesuai fungsi dan keadaan dimasa yang akan datang.

\section{DAFTAR PUSTAKA}

[1] Ambarsari Nia,P.A.Afgan, dan P.A Yuli. Pengembangan Web E-Commerce Bojana Sari Menggunakan Metode Prototype.ISSN : 2355-9365,eProceeding of Engineering : Vol.2, No.1 April 2015.

[2] Ariani Sukamto, Rosa. M.Shalahuddin. 2015. Rekayasa Perangkat Lunak Struktur dan Berorientasi Objek. Bandung : Informatika.

[3] Cholifah,Wahyu Nur., Yulianingsih dan Melati,Sri. SagitaPengujian Black Box Testing pada Aplikasi Action \& Strategy Berbasis Android dengan Teknologi Phonegap, Jurnal String, ISSN 2549 2837, Vol. 3 No.2 Desember 2018. 
[4] Boediono, Teori Ekonomi Mikro, BPFE, Yogyakarta, 2006

[5] Junaedi dan Yulian, Dwi Prabowo(2018).project sistem kendali elektronikberbasis arduino.Bandar Lampung. CV.Anugrah Utama Raharja.

[6] Arsada, Uno Bakhtiyar. Suprianto, Bambang. 2017. Aplikasi Sensor Ultrasonik Untuk Deteksi Posisi Jarak Pada Ruang Menggunakan Arduino Uno. Jurnal Teknik Elektro, Volume 06 Nomor 02 Tahun 2017.

[7] Nugraha. Rancang Bangun Sistem Monitor Dan Kendali Ruang Laboratorium Berbasis Arduino Ethernet Shield. BUFFER INFORMATIKA : DEPARTMENT of INFORMATICS ENGINEERING p-ISSN :2527-4856, (online)e-ISSN : 2614-5413, Vol.02 No.1, 2016.

[8] Kristanto, A. (2018). Perancangan Sistem Informasi dan Aplikasi. Yogyakarta: Penerbit Gavamedia.

[9].MF, Mundzir. (2018). Buku Sakti Pemrograman Web seri PHP. Bandung: Informatika Bndung.

[10] Winarto, E., \& Zaky, A. (2014). 24 Jam Belajar PHP. Semarang: PT Elex Media Komputindo.

[11] Rosa, A.S dan Salahuddin M. Rekayasa Perangkat Lunak, Informatika. Bandung, 2014 